\title{
Cytomegalovirus IE-1-specific Cytotoxic T Lymphocytes
}

National Cancer Institute

\section{Source}

National Cancer Institute. Cytomegalovirus IE-1-specific Cytotoxic T Lymphocytes. NCI Thesaurus. Code C80052.

Cytotoxic T-lymphocytes (CT LS), specifically reactive to the cytomegalovirus (CMV) immediate early-1 (IE-1) protein, with immunomodulating activity. Adoptive immunotherapy with cytomegalovirus IE-1-specific cytotoxic T lymphocytes may help reconstitute CD8+ cytomegalovirus-specific CTL responses in CMV-infected immunocompromised hosts. IE-1 is one of the first CMV antigens expressed by CMVinfected cells, predominantly inducing a CD8+ CT L response. 